\title{
The Level of Students' Ability in Translating Report Text from Indonesian into English at Universitas Negeri Padang
}

\author{
Annisa Tasyakurna. $\mathrm{M}^{1 *}$ and Hermawati Syarif ${ }^{2}$ \\ ${ }^{12}$ English Department, FBS Universitas Negeri Padang, Padang, Sumatra Barat 25131, Indonesia \\ *Corresponding author.Email: Email:annisatasyakurna@gmail.com; hermawatisy@yahoo.com
}

\begin{abstract}
Translation is an ability that has to be mastered by the students especially to translate report text from Indonesian into English. Report text is one of the genres that should be translated by the students. It aims to analyze students' ability in translating report text. Translating report text is also one of forms in translation class. Translation ability has an important role in increasing students' ability in translating Indonesian into English. Based on the explanation above, this study had a goal in order to determine the students' translation ability in translating report text from Indonesian into English. Furthermore, the subjects of this study were English Education Department students of Universitas Negeri Padang. This study was descriptive research to describe and analyze the existed condition in the field. This study was conducted by translation test to gather students' translation ability to translate report text from Indonesian into English. As a result of the study, the test of translation ability was identified and classified based on several indicators. It consisted of accuracy, acceptability, and readability. From the analysis it is revealed that there were three students' level is good, only one student gained fairly good level, and the other three students obtained almost good level, and also three students obtained fair level, while no one students obtained poor level.In conclusion, in general that the students' ability to translate report text is fairly good.
\end{abstract}

\section{Keywords: Ability, Report Text, Translating}

\section{INTRODUCTION}

Language is an essential tool for everyone in the world to communicate information. People use language to communicate anything they want to communicate, including ideas, thoughts, and facts. One of the most crucial skills that people who wish to interact with others must master is translation. It is necessary to understand the goal meaning of the language used in order to communicate effectively with others; if someone does not understand it, communication will be difficult. In this situation, people who try to talk with others need be aware of the language's meaning, which may be obtained through translation. The translation is a translation process that transfers meaning from one language to another. It is the process of transferring a source language (SL) into a target language (TL) in such a way that the two languages surface meanings are nearly identical and the structure is kept as closely as possible without severely distorting the TL structures
(Basnett) [1]. Translation not only changes English words into Indonesian terms for the real meaning, but depends also on the context of the word. Meanwhile, Hatim and Munday [2] have defined translations as the act of moving a written document from source to destination language. The goal of the translation is to identify in TL the corresponding meaning in the SL.

In terms of the difficulties presented by various texts, each text has a different level of difficulty to translate. Report text is one of the more challenging texts to translate. Report text is categorized as a textbased on the content of the source language, in order for the students to be more aware to the equivalence of meaning, delivering message, making this translation understandable for the readers.

In transferring the meaning of a text into a good translated text is not an easy thing to do. There are many scholars have conducted studies difficulties on translation in different text. Research by Hadrus [3], he analyzed about students difficulties in translating 
Argumentative text at the second grade students of SMA Negeri 1 Lappariaja. He described that students' difficulties to translate argumentative text were the difficulties in linguistic factors which are more prominent than the non-linguistic factors.

In producing good quality translation product, some problems faced by the student translators. These problems are not only found in the translating process, but also identified from the translation product. As an example, research by Arono and Nadrah [4] analyzed the students' difficulties in translating English text. The difficulties were found by the students in translating report text. While their difficulties translating text were found to be a word choice, difficulty interpreting Islamic text, works of literature, and grammatical issues.

Based on previous explanation, the study that analyze the product of translation report text done by student translators need to be done in order to not only find problems in the translation product but also to get the update of the teaching process in the translation subject later on.

Another study is from Savitri [5] who analyzed the quality of the students' translation to translate an informative text entitles YSEALI into Indonesian. Different from the previous study in which the booklet was translated by a professional translator, the text in this study was translated by student translators. She analyzed the three aspects of the translation of quality (accuracy, readability, and acceptability) from the translation test using Nababan's [6] scale of translation quality and categorized the result into three level of category. It is found that the students' translation quality was fair as it is not great and also not bad because of one aspect which percentage is too low. Other studies also analyzed the quality of translation such as in translating informative text [7]; Putri [8], novel [9, 10], songs [11], abstracts from Thai to English [12], a book [13], and comic [14].

In order to avoid ambiguity and difficulty in the translation product, a successful translation must meet certain criteria such as accuracy, acceptability, and readability. Larson [15] defines translating ability as having three main aspects: correctness, naturalness, and clarity. Meanwhile, according to Sofyan and Tarigan [16], the aspects of measuring translation ability include accuracy, meaning equivalence, translation skill, text function, grammar, and TT style.

From the explanation about assessing of the translation, this research used Nababan's theory [6] to assess the translation of report text, they are: 1) According to Nababan [6], accuracy is a term used to determine whether or not the translation refers to the text of SL and the text of TL. While, Molina and Albir [17], accuracy refers to whether or not a translation fulfills certain criteria. On the level of meaning, the concept of equivalence refers to the transfer of the same content or message from the source language (SL) to the target language (TL). 2) Nababan [6] argues that acceptability relates to whether a translation has been disclosed in line with the structure, norms, and culture of TL, and micro and macro levels. A translator should apply suitable procedures, utilize relevant phrases in TL, and adjust culture to TL in order to make an acceptable translation that sounds natural. If the translation in the target language is not suitable with binding standards and cultural standards, the results are regarded to be unsatisfactory. If the translation does not conform to target language rules, standards and culture, the interpretation would not be natural and would not be rejected by the target audience. 3) According to Larson [18] readability is determined by diction, sentence structure and order, pronunciation, and punctuation. While, Nababan [6] readability is a measure of how well it is understood by its target readers. In addition, Dubay [19] readability is the process to determine the correct approach and techniques of translation to match the source text to enable readers to readily understand the source text. An interpreter should determine who will read the translation in order to adapt its translation. This is the readability evaluation tool.

On the basis of any of the criteria mentioned of translation ability, it may be inferred that the accuracy, acceptability and readability nature of the translators to translate the text can be applied for the purpose of determining translation ability.

\section{METHODS}

This research belongs to qualitative, since it encourages a thorough about the ability in translating report text. Creswell [20] describes qualitative research is used to analyze and comprehend the importance of a social or human issue that people or groups identify. The participants of this research were the English Department students in Universitas Negeri Padang. The researcher also used a translation test as an instrument to collect data for this research. The report text was translated by English Department students at Universitas Negeri Padang for this research. The sample size of this research was ten students.

The source of the data was the Report text from an article who discussed about animal science. The researcher collected data on the students' ability to translate report text by asking them to translate report text. Translated text was analyzed sentence by sentence 
to figure out the level of learners' skill to translate report text from Indonesian into English. The data were analyzed using theory from Nababan [6].

\section{RESULT AND DISCUSSION}

The text provided is report text which contains scientific terms entitled Elang. The text consists of one paragraph of general classification and two paragraphs of description. The following table shows the result:

Table.1 Students' Score and the Level

\begin{tabular}{|l|c|c|c|c|l|}
\hline No. & Acr & Acp & Rdb & Mn & \multicolumn{1}{|c|}{ Lv } \\
\hline S1 & 77 & 68 & 71 & 72 & Good \\
\hline S2 & 64 & 60 & 67 & 64 & Almost Good \\
\hline S3 & 64 & 65 & 65 & 65 & Fairly Good \\
\hline S4 & 65 & 65 & 63 & 64 & Almost Good \\
\hline S5 & 59 & 57 & 57 & 58 & Fair \\
\hline S6 & 63 & 60 & 51 & 58 & Fair \\
\hline S7 & 75 & 78 & 70 & 74 & Good \\
\hline S8 & 66 & 60 & 66 & 64 & Almost Good \\
\hline S9 & 56 & 51 & 65 & 57 & Fair \\
\hline S10 & 73 & 70 & 72 & 72 & Good \\
\hline $\begin{array}{c}\text { Total mean } \\
\text { score }\end{array}$ & 65 & Fairly good \\
\hline
\end{tabular}

$$
\begin{array}{ll}
\mathrm{S}=\text { student } & \text { Acr=accuracy } \\
\text { Acp=acceptability } & \mathrm{Rdb}=\text { readability } \\
\mathrm{Mn}=\text { mean } & \mathrm{Lv}=\text { level }
\end{array}
$$

The frequency of students' translation ability at the English Education Department of Universitas Negeri Padang is shown in the table above. The data in the table above reveals that students' ability to translate report text has a wide range of mean scores. The results presented in table above revealed that the students' ability in translating report text, the researcher got the result that there are three students' level is good. The report result showed that students scored who obtained 70-74, which indicated a good level. There is one student gained fairly good level, the report result showed that students scored 65-69, which indicated a fairly good level. Next, there are three students whose mastery level is almost good, the report result showed that students scored 60-64, which indicated almost good level. And then, there are three students' mastery level is fair. The report result showed that students scored who obtained 55-59, which indicated a fair level. None students scored less than 40 , which indicated a poor level.

\section{CONCLUSION}

Based on the result and discussion of the study on the level of students' ability to translate report text at Universitas Negeri Padang entitles Elang from English into Indonesia, it is concluded there are three students' level is good, only one student gained fairly good level, and the other three students obtained almost good level, and also three students obtained fair level, while no one students obtained poor level. In addition, it can be said in general that the learners' ability to translate report text is fairly good.

\section{AUTHORS' CONTRIBUTIONS}

This paper presents the result analysis the level of students' ability in translating report text in the background of the problem of a thesis by the undergraduate students English education department of Universitas Negeri Padang. In reaching the goal of this study the researcher analyzed the students' ability based on accuracy, acceptability, and readability by Nababan.

\section{ACKNOWLEDGMENTS}

The researcher would like to thanks to Allah S.W.T. who has given the grace and gifts to write this paper. Then, thanks to the advisor Prof. Dr. Hermawati Syarif, M.Hum. finally, the researcher wishes to express his or her heartfelt gratitude goes to parents and friends who have given support, prayer and motivation.

\section{REFERENCES}

[1] Bassnett, Susan. (2005). Translation Studies, 3rd. London and New York.

[2] Hatim, B. Munday (2004). Translation: an advanced resource book.

[3] Hadrus, M. S. (2017). The Analysis of students Difficulties in Translating Argumentative Text from Englih to Indonesian (Doctoral dissertation, Universitas Islam Negeri Makassar).

[4] Arono, A., \& Nadrah, N. (2019). Students'ifficulties In Translating English Text. Joall (Journal of Applied Linguistics and Literature), 4(1), 88-99.

[5] Savitri, Y. (2018). An Analysis Of Students'translation Quality (Accuracy, Readability And Acceptability) In Translating An Informative Text Entitled Yseali To Indonesian.

[6] Nababan, M., Nuraeni, A., \& Sumardiono. (2012). Pengembangan Model Penilaian Kualitas Terjemahan. Kajian Linguistik Dan Sastra, 24(1).

[7] Pratama, A. A., Ramadhan, T. B. L., Elawati, F. N., \& Nugroho, R. A. (2021). Translation Quality Analysis of Cultural Words in Translated Tourism Promotional Text of Central Java. Journal of English Language Teaching and Linguistics, 6(1), 179-193. 
[8] Putri, R. S. (2021). A Translation Quality Assessment On Medan City Tourism Official Web Pages.

[9] Ningsih, R., \& Pulungan, A. H. (2021). The Assessment Of Translation Quality In Bound Novel. Linguistik Terapan, 17(3), 258-263.

[10] Ardi, H.; Nababan, M.R.; Djatmika, D; Santosa, R. (2018). Characters' Politeness Strategies in Giving Command: Should Translators Keep Them? 3L: Language, Linguistics, Literature ${ }^{\circledR} 24$ (2).

[11] Wardani, I. K., \& Yuliasri, I. (2020). Translation Quality of English-Javanese Songs by Pentul Kustik Band. English Education Journal, 10(1), 18-27.

[12] Tongpoon-Patanasorn, A., \& Griffith, K. (2020). Google Translate and Translation Quality: A Case of Translating Academic Abstracts from Thai to English. PASAA: Journal of Language Teaching and Learning in Thailand, 60, 134-163.

[13] Aiman, A., \& Yunianti, F. S. (2020, December). Translation quality and techniques in the book alWajeez by Abdul-Azim al-Khalafi. In Islam in World Perspectives Symposium (Vol. 1, No. 1, pp. 251-272).

[14] Andria, R. \& Ardi, H. (2021). The Ability in Producing Acceptable Indonesian Translation of Comic Strip Made by Students of English Language Education Program of Universitas Negeri Padang. Journal of English Language Teaching 10 (2), 243-251.

[15] Larson, M.L. (1988). Meaning-Based Translation: A guide to Cross Language Equivalence. Lanham: University Press of America.

[16] Sofyan, Rudy \& Bahagia Tarigan. (2018). Developing a Holistic Model of Translation Quality Assessment. Advances in Social Science, Education and Humanities Research, volume 254, Atlantis Press.

[17] Molina, L., \& Hurtado Albir, A. (2002). Translation techniques revisited: A dynamic and functionalist approach. Meta: Journal des Traducteurs/Meta: Translators' Journal, 47(4), 498512.

[18] Larson, M.L. (1984). Meaning-Based Translation: A guide to Cross Language Equivalence. Lanham: University Press of America.

[19] Dubay, W. H. (2004). The principles of readability. California: Impact Information.

[20] Creswell, J.W. (2004). Research design: qualitative, quantitative and mixed method approached. United States of America: SAGE Publications. Inc. 